\title{
Determination of ochratoxin A in coffee by ELISA method and its relationship with the physical, physicochemical and microbiological properties
}

\author{
Determinación de ocratoxina A en café mediante \\ método ELISA y su relación con las propiedades físicas, \\ fisicoquímicas y microbiológicas
}

Robinson Monsalve-Atencio, Ing $\left.{ }^{1 *} \mathbb{( \mathbb { D }}\right)$ Karolay Sánchez, Ing ${ }^{1}\left(\mathbb{D}\right.$, Jairo Camaño, Ing ${ }^{1}$, Seneida Lopera-Cardona, PhD ${ }^{1,30}$, B́lanca Ortiz-Reyes, PhD²(1).

\begin{abstract}
Background: Coffee is one of the most consumed beverages in the world; however, it may contain toxic compounds such as ochratoxin A (OTA). Objectives: Determine the OTA's presence in different types of coffee, intended for beverage preparation and marketed in Colombia through the application of the enzyme-linked immunosorbent assay (ELISA) and analyze its relationship with the physical, physicochemical and microbiological properties. Methods: 8 samples of coffee commercialized in the Colombian market were selected, in which the OTA content was determined by applying the ELISA method. Likewise, a microbiological analysis was performed, and physicochemical properties were determined, such as moisture content, $a_{w^{\prime}}$ percentage total dissolved solids (\%TDS), and extraction yield (\%EY). Physical properties such as free-flow densities, compacted bulk densities (CBD), porosity, average particle size (ASP), and color. The data were treated with multivariate analysis using Principal Component Analysis (PCA) and Cluster Analysis (CA) to quantitatively investigate the relationships between the coffee samples concerning their physical, physicochemical properties, and OTA content. LSD test was applied with a significance level of $95 \%$ and Pearson correlation test. Results: All the samples had OTA content, but only 2 exceeded the limits allowed by the regulations, with a maximum value of $15.449 \mathrm{\mu g} / \mathrm{Kg}$, which represents $31.449 \%$ of the tolerable daily intake according to the parameters defined by Joint FAO/WHO Expert Committee on Food Additives (JECFA). According to the PCA and CA, the samples were grouped harmonically according to the type of coffee associated with its commercial presentation and industrial process, OTA content, and ASP. OTA content was significantly and positively correlated $(p<$ $0.05)$ with \%EY, \%TDS, ASP, porosity, CBD and moisture. Conclusions: The coffees marketed in Colombia showed a variable range of OTA, where soluble coffees had higher OTA contents than roasted coffees, and $25 \%$ of the coffees analyzed do not meet the levels defined by Colombian regulations. The OTA content in coffee is related to properties that define the ability to extract solutes from coffee.
\end{abstract}

Keywords: Soluble coffee; Ochratoxin A, ELISA, Principal Component Analysis; Ground roasted coffee.

Robinson Monsalve Atencio robinson.monsalve@udea.edu.co

Received: 17 September 2020 Accepted: 17 March 2021 Published: 22 May 2021 


\section{RESUMEN}

Antecedentes: El café es una de las bebidas más consumidas en el mundo, sin embargo, puede contener compuestos tóxicos como la ocratoxina A (OTA). Objetivos: Determinar la presencia de OTA en diferentes tipos de café destinados a la preparación de bebida y comercializados en Colombia mediante la aplicación del ensayo inmunoabsorbente ligado a enzimas (ELISA) y analizar su relación con las propiedades físicas, fisicoquímicas y microbiológicas. Métodos: Se seleccionaron 8 muestras de café comercializado en el mercado colombiano, en las cuales se determinó el contenido de OTA mediante la aplicación del método ELISA. Así mismo se realizó análisis microbiológico y se determinaron propiedades fisicoquímicas como contenido de humedad, $a_{w^{\prime}}$ porcentaje de sólidos disueltos totales (\%TDS) y rendimiento de extracción (\%EY); y propiedades físicas como densidad por caída libre, densidad compactada (CBD), porosidad, tamaño promedio de partícula (ASP) y color. Los datos fueron tratados con análisis multivariado empleando análisis de componentes principales (PCA) y análisis de conglomerados (CA) para investigar cuantitativamente las relaciones entre las muestras de café con respecto a sus propiedades físicas, fisicoquímicas y contenido de OTA. Se aplicó prueba LSD con un nivel de significación del 95 \% y prueba de correlación de Pearson. Resultados: Todas las muestras presentaron contenido de OTA, pero solo 2 sobrepasaron los límites permitidos por la normatividad, con un valor máximo de $15.449 \mu \mathrm{g} / \mathrm{Kg}$, el cual representa un $31.449 \%$ de la ingesta diaria tolerable según los parámetros definidos por el Comité Mixto FAO/OMS de Expertos en Aditivos Alimentarios (JECFA). De acuerdo al PCA y CA, las muestras se agruparon armónicamente de acuerdo al tipo de café asociado a su presentación comercial y proceso industrial, contenido de OTA y ASP; el contenido de OTA se correlacionó significativa y positivamente $(p<0.05)$ con el \%EY, \%TDS, ASP, porosidad, CBD y humedad. Conclusión: Los cafés comercializados en Colombia presentan un rango variable de OTA, en donde los cafés solubles presentan contenidos de OTA mayores que los cafés tostados y el $25 \%$ de los cafés analizados no cumplen con niveles definidos por la normatividad colombiana. El contenido de OTA en el café está relacionado con propiedades que definen la capacidad de extracción de solutos del café.

Palabras Clave: Café soluble; Ocratoxina A, ELISA, Análisis de componentes principales, Café tostado y molido.

\section{INTRODUCTION}

Coffee is one of the most appreciated and consumed beverages in the world (1); however, in its various states, it is susceptible to present a risk of contamination by mycotoxins (2). Mycotoxins are secondary metabolites produced by filamentous fungi that are present in agricultural products due to inadequate food handling and poor storage methods $(3,4)$. Several toxigenic fungi such as Fusarium spp., Aspergillus spp., and Ochratoxigenic species have been found in coffee plants, coffee beans, and roasted coffee worldwide (3). Thus, mycotoxins contents have been reported in coffee (e.g., sterigmatocystin (STG), aflatoxin $B_{2}\left(F B_{2}\right)$, aflatoxins (AFs), and ochratoxin A (OTA)) (3). To date, several potentially toxigenic fungal toxins such as those mentioned above, have been found in Colombian coffee beans, including all steps of coffee processing (5), which indicates these toxins in Colombian coffee samples could be present.

OTA is one of the most important and harmful mycotoxins (2), which is a metabolite produced by filamentous fungi of the genus Aspergillus and Penicillium, in particular, $A$. ochraceus and $P$. verrucosum $(6,7)$. OTA is nephrotoxic, hepatotoxic, embryotoxic, teratogenic, neurotoxic, immunotoxic, genotoxic, and carcinogenic in many species with species and sex-related differences (2), so the presence of this toxin in coffee is a public health concern, particularly for heavy drinkers (8). OTA is a low molecular weight ubiquitous secondary metabolite, a weak organic acid consisting of phenylalanine amino acid and a dihydro-isocoumarin linked by a peptide bond, giving interesting chemical characteristics such as low aqueous solubility and high in organic compounds (8) (Fig. 1).<smiles>C[C@@H]1Cc2c(Cl)cc(C(=O)N[C@@H](Cc3ccccc3)C(=O)O)c(O)c2C(=O)O1</smiles>

Figure 1. Structural formula of OTA.

In Colombia, coffee has an important participation in the national economy. According to the National Federation of Coffee-Growers (FNC), the Arabian coffee exportation represents $11.3 \%$ of world exports (9), and the product goes to more than 50 countries (10). Colombian regulations established the maximum OTA limits for roasted and soluble coffee, with values of $5 \mu \mathrm{g} / \mathrm{kg}$ and soluble $10 \mu \mathrm{g} / \mathrm{kg}$, respectively (11), in agreement with the same limits established by international regulations such as the European Commission (12). Regarding the coffee for consumption, there are different formats on the market, such as roasted ground or whole grain, with various roasting degrees (light, medium, or high) and different grinding levels. On the other hand, consumers can find instant or soluble coffees, which could be agglomerated, freeze-dried, and fine 
powdered. It is also possible to find decaffeinated, flavored, special coffees, among others (13).

There are deeply sensitive and specific analytical techniques for the OTA quantification in different matrices, such as high-performance liquid chromatography (HPLC), liquid chromatographymass spectrometry (LC-MS), gas chromatography (GC), and thin-layer chromatography (TLC). However, these require complex equipment, long assay time, high costs $(14,15)$, and consequently, the lack of such techniques reduces the internal control capacity in coffee production. Therefore, the enzyme-linked immunosorbent assay (ELISA) has become the most widely used immunoassay technique due to its high performance, specificity, robustness, and easy automation (14). This technique is based on a competitive and heterogeneous essay, where the toxin from the sample competes with a labeled toxin (such as a toxin-enzyme conjugate) for a limited number of antibody-binding sites (16) and has been compared with HPLC, finding that both methods are consistent $(17,18)$. However, although the ELISA technique has been used for the OTA determination in coffee $(19,20)$, there are still no reports evaluating its relationship with the physical and physicochemical properties of coffee. This research aimed to determine the OTA presence in different types of coffee destined for beverage preparation and marketed in Colombia by applying the ELISA method and analyzing for the first time its relationship with physical, physicochemical, and microbiological properties.

\section{MATERIALS AND METHODS}

\section{Reagents and materials}

Immunoaffinity columns covered with sepharose gel suspension conjugated with monoclonal antibodies specific for the OTA; microtiter plate with 96 wells (12 strips with 8 wells each) coated with specific antibodies against OTA; 6 OTA standard solutions: 0 part per trillion (ppt) (zero standard), 50 ppt, 100 ppt, 300 ppt, 900 ppt, 1800 ppt in aqueous solution; peroxidase conjugate OTA; conjugate buffer; substrate/chromogen (tetramethylbenzidine); stop solution (corresponding to $1 \mathrm{~N}$ sulfuric acid); 10 $\mathrm{mM}$ wash buffer phosphate, $\mathrm{pH} 7.4$ (0.05\% Tween 20), were obtained from test-kits of RIDASCREEN ${ }^{\circledR}$ Ochratoxin A and RIDA ${ }^{\circledR}$ Ochratoxin A (R-Biopharm, Darmstadt, Alemania). All other inorganic reagents, chemicals, and organic solvents were of analytical grade.

\section{Samples}

Eight coffee samples were selected (Table 1) according to availability in the Colombian market. The coffee type per preparation was considered (soluble or roasted for extraction), and the kind of industrial process reported by the manufacturer. Three of the samples acquired corresponded to roasted coffee, which included whole beans, subdivided into premium or excelsior (WB1) and standard (WB2) coffee, and ground roasted coffee (GR). The whole beans samples were ground in a coffee mill (Wega ${ }^{\circledR}$, Medellín, Colombia). The other five samples corresponded to dehydrated coffee extracts for instant soluble drinks, classified as follows: spray-dried coffee (SD), freeze-dried (FD), and agglomerated coffee (A), and including aspects such as origin denomination, excelsior, and decaffeinated coffee. Two groups were formed; the first corresponded to roasted whole beans and ground coffee, and the second to instant soluble particulate coffees. All coffee samples were stored at room temperature; in a cool, dry storage area. All commercially packaged coffees were opened fresh on each trial day.

Table 1. Selection of types of coffee for beverage preparation

\begin{tabular}{llll}
\hline \multicolumn{1}{c}{ Types of coffee } & Preparation of beverage for consumption & Code & Commentary \\
\hline \multirow{2}{*}{ Whole roasted beans } & Infusion grinding and extraction & WB1 & Excelsior \\
& Extraction by infusion & WB2 & Standard \\
\hline Ground roasted beans & Spray Drying - Fine Powder & GR & Standard \\
\hline & For instant beverage & SD1 & With caffeine \\
& Spray Drying - Agglomerate. & A1 & Denomination of origin \\
Dehydrated Particulate Coffee Extract & For instant beverage - & A2 With caffeine \\
& Freeze-dried - Agglomerate. & FD1 Decaffeinated \\
& For instant beverage - & FD2 With caffeine \\
\hline
\end{tabular}




\section{Analysis of ochratoxin A levels using the ELISA method}

\section{Sample preparation}

Performed according to provider guidelines RIDASCREEN ${ }^{\circledR}$ Ocratoxin $A$ in combination with RIDA ${ }^{\circledR}$ Ochratoxin A columns (R-Biopharm ${ }^{\circledR}$, Darmstadt, Alemania) (21). $5 \mathrm{~g}$ of ground coffee were weighed and mixed with $5 \mathrm{~mL} 0.13 \mathrm{M} \mathrm{NaHCO}_{3}$ buffer solution, $\mathrm{pH} 8.1$, and methanol/water (25/75 $\mathrm{v} / \mathrm{v}$ ) using an immersion mixer (Imusa ${ }^{\circledR}$, Medellín, Colombia) and vortex (Daigger Vortex-Genie $2^{\circledR}$, Bohemia, NY, USA). Then centrifuged for 10 min/4000 g (Sorvall ST 16R ${ }^{\circledR}$, Bogotá, Colombia), the supernatant was filtered with a paper filter (Whatman ${ }^{\circledR}$ No.1 $\varnothing=180 \mathrm{~mm}$, Medellín, Colombia) and $5 \mathrm{~mL}$ of the filtrate (corresponding to $1 \mathrm{~g}$ of sample) was diluted with $5 \mathrm{~mL}$ of PBS buffer (Phosphate-buffered saline), pH 7.4. Solid-phase extraction was applied with RIDA ${ }^{\circledR}$ Ochratoxin A column, treated with $2 \mathrm{~mL}$ of PBS/methanol (90/10 $\mathrm{v} / \mathrm{v}$ ) without allowing the matrix to dry, then the column was fed stepwise with $10 \mathrm{~mL}$ of the diluted sample, and it was drained at a flow rate of 1 drop/s employing vacuum application, with $20 \mathrm{inHg}$ Regulator vacuum pump (BIO-RAD ${ }^{\circledR}$, California, EE. UU) coupled to solid-phase extraction system with maximum vacuum capacity of $20 \mathrm{inHg}$. The eluent was collected in a vial that was subsequently diluted in a 1:30 $(1+29)$ ratio with $\mathrm{NaCO}_{3} 0.13 \mathrm{~N}$ buffer and protected from light for further analysis.

\section{ELISA Determination}

The method was applied according to the protocol of the supplier of the quantitative test kit for OTA, R-Biopharm, RIDASCREEN ${ }^{\circledR}$ Ocratoxin A (R-Biopharm ${ }^{\circledR}$, Darmstadt, Alemania), which has a detection limit of $1.25 \mu \mathrm{g} / \mathrm{Kg}$, a recovery percentage of approximately $100 \%$, and specificity for OTA of $100 \%$ (22). Quantification was performed by photometric measurement at $450 \mathrm{~nm}$ using an absorbance microplate reader EL800 (BioTek Instruments INC ${ }^{\circledR}$, Winooski, VT, EE. UU), where the absorption is inversely proportional to the OTA concentration in the sample. The calibration curve was obtained with 6 standard solutions of OTA $(0$, $50,100,300,900$, and $800 \mathrm{ng} / \mathrm{Kg}$ ), and all the data obtained from the experiment were processed through the RIDA ${ }^{\circledR}$ SOFT Win software (Art.Z9999, R-Biopharm ${ }^{\circledR}$, Darmstadt, Alemania) specific for OTA.

\section{Physicochemical analysis}

Moisture content, water activity $\left(a_{w}\right)$, and $\mathrm{pH}$ measurement

A moisture analyzer (Axis $₫$, Bogotá, Colombia) was used to determine the moisture content, based on thermogravimetric analysis using an analytical balance with an infrared lamp (23). The $a_{w}$ of the medium was measured by the hygrometric principle method, using the $a_{w}$ measuring equipment (Pawkit ${ }^{\circledR}$, São Paulo, Brasil), previously calibrated with the salts $\mathrm{LiCl}\left(0.250 \mathrm{a}_{\mathrm{w}}\right)$ and $\mathrm{NaCl}\left(0.760 \mathrm{a}_{\mathrm{w}}\right)$ (24). The $\mathrm{pH}$ value was measured at $25{ }^{\circ} \mathrm{C}$ using a pH meter (Trans Instruments BP $3001^{\circledR}$, Singapore) (25).

Percentage total dissolved solids (\%TDS) and extraction yield (\%EY)

Soluble coffee beverage (26) and roasted and ground coffee were prepared using the drip method (27), where $7 \mathrm{~g}$ of coffee were weighed on a paper filter, and $100 \mathrm{~mL}$ of boiling water were added, slowly, continuously, and with circular movements in a time of $30 \mathrm{~s}$. The TDS content of all the coffee samples was made using the coffee TDS refractometer (VST inc ${ }^{\circledR}$, Boston, EE. UU) (21), and the \%EY was estimated using the Vst Coffee tools software (26).

\section{Physical properties analysis}

\section{Colorimetric parameters}

Colorimetric parameters were determined with a colorimeter-spectrophotometer (ColorFlex ${ }^{\circledR} \mathrm{EZ}$ HunterLab, Reston, USA), with a spectral range of $400-700 \mathrm{~nm}$, and standard illuminant D65, measuring CIE L*a*b* (CIE L* (white/black), CIE a* (redness/greenness), CIE b* (yellowness/blueness)).

Free-flow (FLD) and compacted bulk densities, and porosity

Free-flow (FLD) and compacted bulk densities (CBD) were determined according to Colombian Technical Standard NTC (NTC) 4912 (28). Porosity was determined according to concepts and methods reported for particles in assembly (29).

\section{Particle size}

The average particle size (APS) was determined according to NTC 2441 (30), through fraction 
separation according to the particle size distribution using sieves powered by a Ro-Tap ${ }^{\circledR}$, Laval, Canadá.

\section{Microbiologic analysis}

Yeast and mold counts were performed using Oxytetracycline-Glucose-Yeast Extract Agar (OGYE Agar) (Merck KGaA, Germany) according to AOAC 997.02 (24), and the results were reported in UFC/g. They were compared to Colombian regulations for coffee NTC 4159 and 3435 (31,32).

\section{Statistical analysis}

Samples were evaluated in triplicate, coded, and randomly analyzed. Principal component analysis (PCA) and cluster analyses (CA) were used to quantitatively investigate the relationships between the coffee samples concerning their physical, physicochemical, and safety properties (OTA content), and principal components with eigenvalues greater than one were selected. CA was made through Ward's methods using square Euclidean distances. ANOVA was applied to the results, and differences between samples were established using the LSD test with a level of significance of $95 \%$. The correlations between the variables were evaluated using the Pearson correlation test. For this purpose, the coffee samples were grouped into two groups, the first corresponding to roasted coffee, while the second referred to soluble coffee. All statistical analyzes were performed in StatGraphics Centurion XVII ${ }^{\circledR}$.

\section{RESULTS}

\section{Ochratoxin A analysis and physicochemical properties}

As shown in Fig. 2, a standard competitive inhibition curve was established by plotting $B / B_{0}(\%)$ against OTA concentrations with the RIDA ${ }^{\circledR}$ SOFT Win version (Art.Z9999, R-Biopharm ${ }^{\circledR}$, Darmstadt, Alemania), where $B$ is the absorbance at $450 \mathrm{~nm}$ in the presence of OTA and $B_{0}$ is the absorbance at $450 \mathrm{~nm}$ in its absence. It is important to mention that the curves obtained by the method do not follow a linear model $(22,33)$.

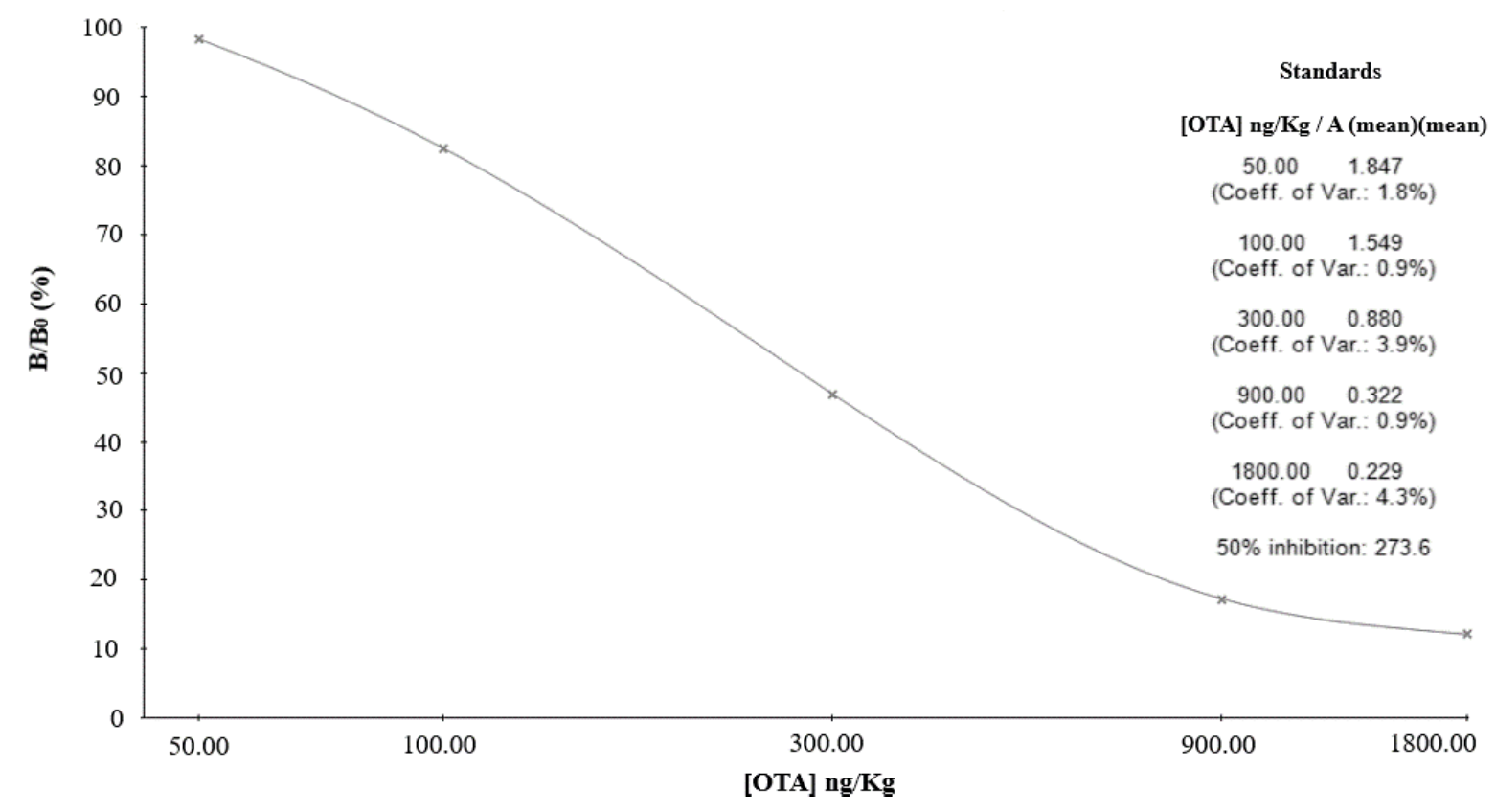

Figure 2. Indirect competitive ELISA standard curve. 
The results obtained from the analysis of the physicochemical properties and analysis of OTA are shown in Table 2. A highly variable incidence of OTA in coffee samples is observed, where soluble coffees presented significantly $(p<0.05)$ higher OTA contents compared to roasted coffees. The presence of OTA was detected in $100 \%$ of the samples analyzed, for which all showed significant differences $(p<0.05)$, and two of the samples evaluated (25\%) exceeded the limits set by legislation for OTA content in coffee, one of these was for roasted and ground coffee (GR) exceeding the maximum permitted level of $5 \mu \mathrm{g} / \mathrm{Kg}(11,12)$, with a value of $5.287 \mu \mathrm{g} / \mathrm{Kg}$. The other sample referred to an agglomerated soluble coffee (A2) that exceeded the maximum permitted level of $10 \mu \mathrm{g} / \mathrm{Kg}(11,12)$, with a value of $15.449 \mu \mathrm{g} / \mathrm{Kg}$. In contrast, the lowest OTA value was obtained for the WB2 sample with a $0.868 \mu \mathrm{g} / \mathrm{Kg}$ content.

Table 2. Physicochemical properties and OTA content in Colombian commercial coffees

\begin{tabular}{|c|c|c|c|c|c|c|}
\hline Sample & Moisture (\%) & $\mathrm{pH}$ & $a_{w}$ & \%TDS & \%EY & OTA $(\mu \mathrm{g} / \mathrm{Kg})$ \\
\hline \multicolumn{7}{|c|}{ Roasted } \\
\hline WB1 & $3.006 \pm 0.109^{c}$ & $4.930 \pm 0.020^{a}$ & $0.510 \pm 0.010^{d}$ & $1.100 \pm 0,100^{b, c}$ & $13.330 \pm 0.060^{b}$ & $1.343 \pm 0.016^{b}$ \\
\hline WB2 & $1.500 \pm 0.116^{\mathrm{a}}$ & $8.730 \pm 2.370^{b}$ & $0.440 \pm 0.010^{c}$ & $0.700 \pm 0.100^{a}$ & $8.530 \pm 0.060^{a}$ & $0.868 \pm 0.009^{a}$ \\
\hline $\mathrm{GR}$ & $4.416 \pm 0.119^{9}$ & $5.230 \pm 0.140^{a}$ & $0.520 \pm 0.010^{d}$ & $1.900 \pm 000^{f}$ & $14.170 \pm 000^{c}$ & $5.287 \pm 0.187^{d}$ \\
\hline \multicolumn{7}{|c|}{ Soluble } \\
\hline SD & $3.347 \pm 0.055^{d}$ & $4.660 \pm 0.000^{\mathrm{a}}$ & $0.430 \pm 0.010^{c}$ & $1.400 \pm 0.100^{d}$ & - & $7.557 \pm 0.626^{\mathrm{g}}$ \\
\hline $\mathrm{A} 1$ & $3.882 \pm 0.006^{f}$ & $4.670 \pm 0.010^{a}$ & $0.450 \pm 0.010^{c}$ & $1.300 \pm 0.100^{d}$ & - & $5.820 \pm 0.213^{e}$ \\
\hline $\mathrm{A} 2$ & $4.382 \pm 0.100^{9}$ & $5.120 \pm 0.110^{a}$ & $0.450 \pm 0.020^{c}$ & $1.000 \pm 000^{b}$ & - & $15.449 \pm 0.102^{h}$ \\
\hline FD1 & $3.605 \pm 0.167^{e}$ & $5.020 \pm 0.150^{\mathrm{a}}$ & $0.330 \pm 0.020^{b}$ & $1.200 \pm 0.100^{c, d}$ & - & $3.491 \pm 0.058^{c}$ \\
\hline FD2 & $2.673 \pm 0.148^{b}$ & $4.770 \pm 0.050^{\mathrm{a}}$ & $0.280 \pm 0.050^{a}$ & $1.600 \pm 0.300^{\mathrm{e}}$ & - & $7.077 \pm 0.021^{f}$ \\
\hline
\end{tabular}

Data were expressed as mean \pm standard deviation $(n=3)$. Different letters in the same column indicate a significant difference $(p<0.05)$. \%TDS: Percentage total dissolved solids, \%EY: extraction yield. For sample codes refer to Table 1.

In Fig. 3, the strengths of the correlations between all the variables analyzed in the coffee samples are shown. The OTA content for roasted coffee samples showed, according to Babu et al. (2014) (34), very strong, significant, and positive correlations $(p<$ $0.05)$ with parameters such as \%TDS, porosity, CBD, moisture content. Moreover, strong with colorimetric parameters $a^{*}$ and $b^{*}$, to moderate with \%EY; in the same way, a strong, significant, and negative correlation $(p<0.05)$ with the APS. While for soluble coffee (Fig. 3.b), the OTA content showed only a significantly strong negative correlation $(p<0.05)$ with the parameter $b^{*}$, and moderate with the APS, while with the moisture content, it showed a significant moderate positive correlation $(p<0.05)$.

On the other hand, the moisture content and $a_{w}$ ranged between $1.500-4.416 \%$ and $0.44-0.52$ for roasted coffee, and $2.673-4.382 \%$ and 0.28 0.45 for soluble coffee, respectively. The moisture content was variable, while the $a_{w}$ was significantly $(p<0.05)$ higher in roasted coffees than soluble. In the case of roasted coffee, the moisture content presented very strong, significant, and positive correlations ( $p<0.05$ ) with the \%TDS, \%EY, OTA content, strong with $\mathrm{a}_{\mathrm{w}}$ and porosity; and moderate with $\mathrm{CBD}$, while it presented a strong, significant and negative correlation $(p<0.05)$ with $\mathrm{pH}$. The $a_{w}$ also presented a significant positive correlation ( $p<0.05)$, very strong with \%EY, and a strong one with \%TDS, as well as a strong, significant, and negative correlation ( $\mathrm{p}<0.05$ ) with $\mathrm{pH}$. On the other hand, in the case of soluble coffee, the moisture content presented a strong, significant and negative correlation ( $p<$ $0.05)$ with the parameter $L^{*}$ and the \%TDS, while a strong, significant and positive correlation $(p<0.05)$ with $\mathrm{a}_{\mathrm{w}}$ and moderate with OTA content. The $\mathrm{a}_{\mathrm{w}}$ also presented a significant negative correlation $(p<0.05)$ and very strong with $L^{*}$, strong with APS, and moderate with \%TDS. In contrast, it presented only a positive significant moderate correlation $(p<0.05)$ with CBD. 
$-1.0$

1.0

\begin{tabular}{|c|c|c|c|c|c|c|c|c|c|c|c|c|c|}
\hline FLD & & 0.83 & 0.49 & 0.32 & 0.54 & -0.20 & -0.60 & 0.24 & 0.14 & -0.24 & 0.45 & -0.10 & 0.60 \\
\hline CBD & 0.83 & & 0.89 & 0.68 & 0.76 & -0.54 & -0.77 & 0.69 & -0.18 & 0.28 & 0.83 & 0.39 & 0.93 \\
\hline Porosity & 0.49 & 0.89 & & 0.81 & 0.76 & -0.70 & -0.70 & 0.87 & -0.38 & 0.61 & 0.91 & 0.67 & 0.95 \\
\hline$a^{*}$ & 0.32 & 0.68 & 0.81 & & 0.84 & -0.95 & -0.31 & 0.63 & -0.04 & 0.44 & 0.70 & 0.47 & 0.74 \\
\hline $\mathbf{b}^{*}$ & 0.54 & 0.76 & 0.76 & 0.84 & & -0.86 & -0.21 & 0.54 & -0.03 & 0.19 & 0.60 & 0.27 & 0.71 \\
\hline $\mathrm{L}^{*}$ & -0.20 & -0.54 & -0.70 & -0.95 & -0.86 & & 0.11 & -0.48 & -0.11 & -0.31 & -0.53 & -0.33 & -0.58 \\
\hline APS & -0.60 & -0.77 & -0.70 & -0.31 & -0.21 & 0.11 & & -0.64 & 0.33 & -0.41 & -0.76 & -0.48 & -0.78 \\
\hline loisture & 0.24 & 0.69 & 0.87 & 0.63 & 0.54 & -0.48 & -0.64 & & \begin{tabular}{|c|}
-0.73 \\
\end{tabular} & 0,87 & 0.95 & 0.93 & 0.90 \\
\hline $\mathrm{pH}$ & 0.14 & -0.18 & -0.38 & -0.04 & -0.03 & -0.11 & 0.33 & -0.73 & & -0.78 & -0.53 & -0.82 & -0.44 \\
\hline aw & -0.24 & 0.28 & 0.61 & 0.44 & 0.19 & -0.31 & -0.41 & 0.87 & -0.78 & & 0.74 & 0.98 & 0.61 \\
\hline$\%$ TDS & 0.45 & 0.83 & 0.91 & 0.70 & 0.60 & -0.53 & -0.76 & 0.95 & -0.53 & 0.74 & & 0.82 & 0.97 \\
\hline$\%$ EY & -0.10 & 0.39 & 0.67 & 0.47 & 0.27 & -0.33 & -0.48 & 0.93 & -0.82 & 0.98 & 0.82 & & 0.69 \\
\hline \multirow[t]{2}{*}{ OTA } & 0.60 & 0.93 & 0.95 & 0.74 & 0.71 & -0.58 & -0.78 & 0.90 & -0.44 & 0.61 & 0.97 & 0.69 & \\
\hline & 号 & 品 & $\begin{array}{l}\frac{7}{10} \\
\text { 잉 } \\
0\end{array}$ & * & مـ & * & $\begin{array}{l}\infty \\
\alpha\end{array}$ & 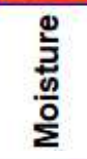 & $\frac{T}{2}$ & $\sum_{\pi}^{3}$ & 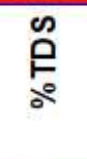 & ఫّ & 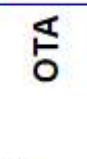 \\
\hline
\end{tabular}

a)

\begin{tabular}{|c|c|c|c|c|c|c|c|c|c|c|c|c|}
\hline FLD & & -0.12 & -0.74 & -0.30 & 0.37 & 0.00 & -0.17 & -0.15 & -0.15 & -0.14 & 0.15 & -0.28 \\
\hline CBD & -0.12 & & 0.75 & 0.54 & -0.33 & -0.58 & -0.01 & 0.51 & -0.24 & 0.55 & -0.11 & 0.14 \\
\hline Porosity & -0.74 & 0.75 & & 0.55 & -0.51 & -0.37 & 0.10 & 0.45 & -0.03 & 0.46 & -0.18 & 0.33 \\
\hline$a^{*}$ & -0.30 & 0.54 & 0.55 & & 0.19 & -0.42 & 0.26 & 0.47 & 0.22 & 0.24 & -0.53 & 0.07 \\
\hline $\mathbf{b}^{*}$ & 0.37 & -0.33 & -0.51 & 0.19 & & 0.18 & 0.27 & -0.36 & -0.17 & -0.39 & 0.04 & -0.76 \\
\hline$L^{*}$ & 0.00 & -0.58 & -0.37 & -0.42 & 0.18 & & 0.65 & -0.79 & 0.04 & -0.93 & 0.66 & -0.35 \\
\hline APS & -0.17 & -0.01 & 0.10 & 0.26 & 0.27 & 0.65 & & -0.35 & 0.21 & -0.72 & 0.40 & -0.43 \\
\hline Moisture & -0.15 & 0.51 & 0.45 & 0.47 & -0.36 & -0.79 & -0.35 & & 0.47 & 0.75 & -0.79 & 0.53 \\
\hline $\mathrm{pH}$ & -0.15 & -0.24 & -0.03 & 0.22 & -0.17 & 0.04 & 0.21 & 0.47 & & -0.09 & -0.58 & 0.44 \\
\hline aw & -0.14 & 0.55 & 0.46 & 0.24 & -0.39 & -0.93 & -0.72 & 0.75 & -0.09 & & -0.59 & 0.45 \\
\hline$\%$ TDS & 0.15 & -0.11 & -0.18 & -0.53 & 0.04 & 0.66 & 0.40 & -0.79 & -0.58 & -0.59 & & -0.52 \\
\hline \multirow[t]{2}{*}{ OTA } & -0.28 & 0.14 & 0.33 & 0.07 & -0.76 & -0.35 & -0.43 & 0.53 & 0.44 & 0.45 & -0.52 & \\
\hline & 곤 & 兽 & $\begin{array}{l}\frac{2}{0} \\
\text { 은 } \\
0 \\
0\end{array}$ & * & م & * & $\begin{array}{l}\infty \\
\frac{0}{\alpha}\end{array}$ & 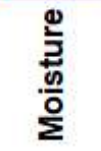 & $\frac{I}{2}$ & క & $\stackrel{\infty}{\frac{\infty}{2}}$ & $\stackrel{\S}{\leftarrow}$ \\
\hline
\end{tabular}

b)

Figure 3. Correlation matrices between parameters related to physical, physicochemical properties, and OTA content for (a) roasted and (b) soluble coffee. FLD: free-flow densities, CBD: compacted bulk densities, APS: average particle size, \%TDS: percentage total dissolved solids.

The $\mathrm{pH}$ ranged between $4.93-8.73$ and $4.66-5.12$ for roasted and soluble coffee, respectively, and roasted coffees showed higher values $(p<0.05)$ than soluble coffees. In addition to the previously mentioned correlations, the $\mathrm{pH}$ presented strong significant negative correlations $(p<0.05)$ with \%EY for roasted coffee and moderate with \%TDS for soluble coffee. Regarding \%TDS, values in the range of 0.7-1.9 and 1.0 -1.4\% were found in roasted and soluble coffee, respectively. In the case of roasted coffee, the \%TDS, in addition to those mentioned above, presented a significant positive correlation $(p<0.05)$, very strong with porosity, and strong with $C B D, \% E Y$ and $a^{*}$; while a strong significant negative correlation $(p<0.05)$ with the APS. On the other hand, the \%TDS in soluble coffee, in addition to the aforementioned correlations, only presented significant moderate correlations $(p<0.05)$ positive with $L^{*}$ and negative with $a^{*}$. For its part, the \%EY ranged between 8.53 and $14.17 \%$ for roasted coffee in which, in addition to the previously mentioned correlations, it presented a significant moderate positive correlation $(p<0.05)$ with porosity.

\section{Analysis of physical and microbiological properties}

The tests corresponding to the yeast and mold counts for all the coffee samples analyzed showed data lower than $10 \mathrm{UFC/g}$ (Table 3), indicating compliance with Colombian regulations for coffee $(31,32)$. 
Table 3. Physical properties and yeast and mold counts of Colombian commercial coffees

\begin{tabular}{|c|c|c|c|c|}
\hline Sample & FLD $(\mathrm{g} / \mathrm{mL})$ & CBD $(\mathrm{g} / \mathrm{mL})$ & Porosity & APS $(\mu \mathrm{m})$ \\
\hline \multicolumn{5}{|c|}{ Roasted } \\
\hline WB1 & $0.275 \pm 0.013^{b}$ & $0.306 \pm 0.006^{c}$ & $0.104 \pm 0.049^{a, b}$ & $614.330 \pm 90.530^{c, d}$ \\
\hline WB2 & $0.319 \pm 0.013^{c}$ & $0.347 \pm 0.011^{d}$ & $0.080 \pm 0.023^{a, b}$ & $613.670 \pm 109.280^{c, d}$ \\
\hline GR & $0.337 \pm 0.009^{c}$ & $0.459 \pm 0.007^{e}$ & $0.267 \pm 0.009^{c, d}$ & $415.330 \pm 90.890^{\mathrm{a}, \mathrm{b}}$ \\
\hline \multicolumn{5}{|c|}{ Soluble } \\
\hline SD & $0.231 \pm 0.010^{\mathrm{a}}$ & $0.250 \pm 0.007^{\mathrm{a}}$ & $0.075 \pm 0.047^{a}$ & $291.670 \pm 66.610^{\mathrm{a}}$ \\
\hline A1 & $0.205 \pm 0.021^{\mathrm{a}}$ & $0.323 \pm 0.009^{c, d}$ & $0.363 \pm 0.073^{d}$ & $518.670 \pm 26.160^{b, c}$ \\
\hline$A 2$ & $0.202 \pm 0.026^{a}$ & $0.280 \pm 0.034^{b, c}$ & $0.277 \pm 0.040^{c, d}$ & $425.670 \pm 34.990^{b}$ \\
\hline FD1 & $0.226 \pm 0.005^{a}$ & $0.246 \pm 0.002^{\mathrm{a}}$ & $0.083 \pm 0.017^{a, b}$ & $614.000 \pm 36.040^{c, d}$ \\
\hline FD2 & $0.207 \pm 0.036^{a}$ & $0.252 \pm 0.013^{\mathrm{a}}$ & $0.182 \pm 0.126^{b, c}$ & $648.670 \pm 67.300^{d}$ \\
\hline \multirow{2}{*}{ Sample } & \multicolumn{3}{|c|}{ Color } & \multirow{2}{*}{$\begin{array}{c}\text { Yeast and mold yeast } \\
\text { counts (UFC/g) }\end{array}$} \\
\hline & $a^{*}$ & $\mathbf{b}^{*}$ & $\mathbf{L}^{*}$ & \\
\hline \multicolumn{5}{|c|}{ Roasted } \\
\hline WB1 & $6.330 \pm 0.910^{\mathrm{a}}$ & $5.530 \pm 1.560^{\mathrm{a}}$ & $25.180 \pm 3.150^{b, c}$ & $<10$ \\
\hline WB2 & $6.280 \pm 1.680^{\mathrm{a}}$ & $6.750 \pm 1.850^{\mathrm{a}, \mathrm{b}}$ & $24.860 \pm 4.850^{a, b, c}$ & $<10$ \\
\hline GR & $8.490 \pm 0.370^{b}$ & $9.500 \pm 1.280^{b}$ & $20.680 \pm 1.020^{a}$ & $<10$ \\
\hline \multicolumn{5}{|c|}{ Soluble } \\
\hline SD & $10.440 \pm 0.210^{c}$ & $16.650 \pm 1.120^{d}$ & $24.850 \pm 1.400^{a, b, c}$ & $<10$ \\
\hline A1 & $13.520 \pm 0.050^{e}$ & $16.480 \pm 0.960^{d}$ & $21.790 \pm 0.800^{a, b}$ & $<10$ \\
\hline A2 & $12.820 \pm 0.260^{d, e}$ & $12.930 \pm 0.910^{c}$ & $22.980 \pm 1.330^{a, b}$ & $<10$ \\
\hline FD1 & $12.470 \pm 0.070^{d, e}$ & $20.610 \pm 0.870^{e}$ & $29.070 \pm 0.610^{c}$ & $<10$ \\
\hline FD2 & $11.650 \pm 1.640^{c, d}$ & $16.490 \pm 4.210^{d}$ & $34.650 \pm 3.070^{d}$ & $<10$ \\
\hline
\end{tabular}

Data were expressed as mean \pm standard deviation $(n=3)$. Different letters in the same column indicate a significant difference $(p<0.05)$. For sample codes refer to Table 1. FLD: free-flow densities, CBD: compacted bulk densities, APS: average particle size.

The results obtained from the analysis of physical properties are shown in Table 3. For roasted coffee, FLD and CBD ranged from $0.275-0.337$ and 0.306 $-0.459 \mathrm{~g} / \mathrm{mL}$, respectively. FLD only presented a strong, significant, and positive correlation $(p<0.05)$ with $C B D$, while $C B D$ presented a significant and positive correlation $(p<0.05)$ strong with porosity and $b^{*}$, and moderate with $a^{*}$; and strong negative with the APS. In the case of soluble coffee, the FLD and CBD ranged between $0.202-0.231$ and $0.246-0.323 \mathrm{~g} / \mathrm{mL}$, respectively, highlighting that the FLD and CBD of soluble coffees were lower ( $p$ $<0.05)$ compared to that of roasted coffees. The FLD only showed a strong, significant, and negative correlation $(p<0.05)$ with porosity. CBD showed a strong positive and significant correlation ( $p<$ 0.05 ) with porosity and moderate with $a^{*}$, while it presented a moderate, significant, and negative correlation with $L^{*}$.

In roasted coffee, porosity and ASP varied in a range of $0.080-0.267$ and $415.33-614.33 \mu \mathrm{m}$; porosity, in addition to the correlations previously shown, presented a strong, significant and positive correlation $(p<0.05)$ with $a^{*}$ and $b^{*}$, and a strong negative correlation with $L^{*}$ and APS. In the case of soluble coffees, the porosity and the ASP varied in a range of $0.075-0.363$ and $291.67-648.67 \mu \mathrm{m}$; in addition to the aforementioned correlations, porosity showed a positive significant moderate correlation with the color parameter $a^{*}$, while ASP also showed a significant positive correlation with $L^{*}$. For roasted coffee, the colorimetric parameters $a^{*}$, $b^{*}$, and $L^{*}$ ranged from $6.28-8.49,5.53-9.50$, and 20.68 - 25.18, respectively, highlighting that soluble coffees presented higher values $(p<0.05)$ of $a^{*}$ and $b^{\star}$ compared to roasted coffees. In addition to the correlations indicated above, parameter $a^{\star}$ had a significantly strong correlation $(p<0.05)$ positive with $b^{*}$ and a negative correlation with $L^{*}$, while $b^{*}$ had a significantly strong negative correlation $(p<$ $0.05)$ with $L^{*}$. For soluble coffee, the colorimetric parameters $a^{*}, b^{*}$, and $L^{*}$ ranged from $10.44-13.52$, $12.93-20.61$, and $21.79-34.65$, respectively.

\section{Principal components analysis (PCA) and cluster analysis (CA)}

PCA was applied to evaluate the relationship between physical, physicochemical properties, and 
OTA content in coffee. Three principal components (PC) were obtained, which explain 95.34 and $75.65 \%$ of the total variance for roasted and soluble coffee, respectively. Fig. 4 shows the biplot (PC2 vs. PC1, PC3 vs. PC1) of samples and coffee variables.

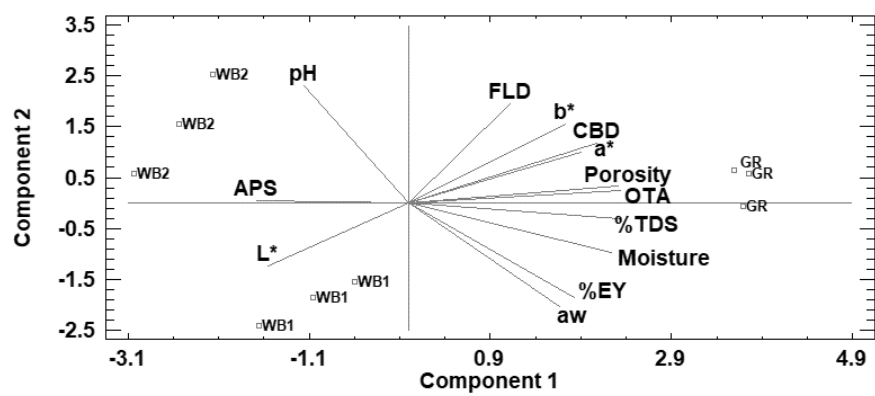

a)

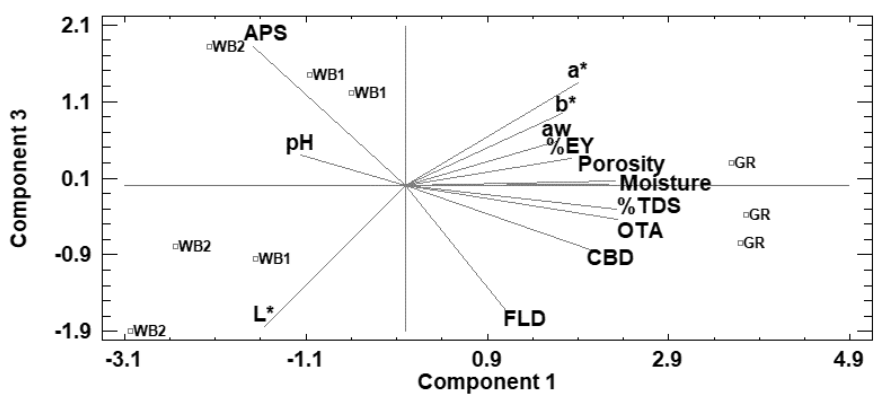

b)

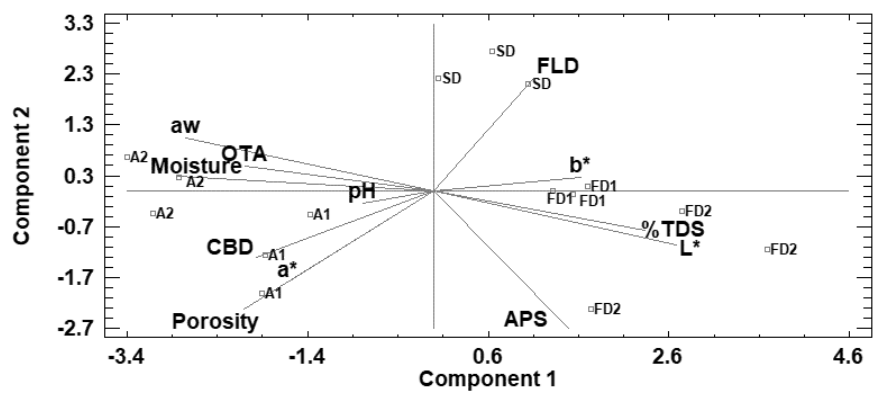

c)

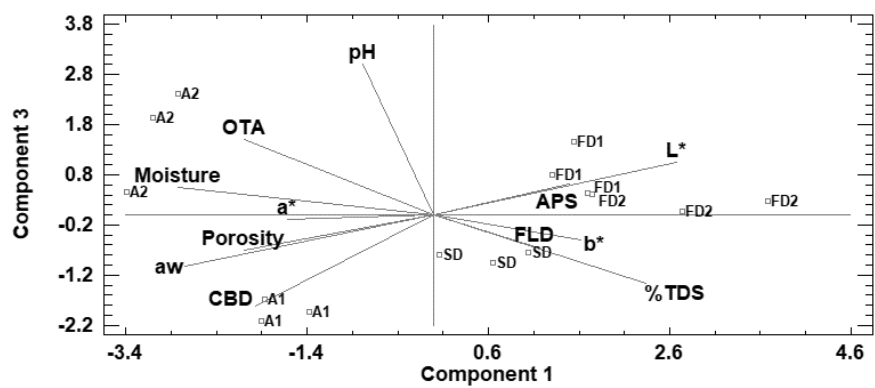

d)

Figure 4. Principal component analysis (PCA) of the Colombian commercial coffees according to the physical determinations, physicochemical properties, and OTA content (a) PC2 vs. PC1 of roasted coffee, (b) PC3 vs. PC1 of roasted coffee, (c) PC2 vs. PC1 of soluble coffee, (d) PC2 vs. PC1 of soluble coffee. FLD: freeflow densities, CBD: compacted bulk densities, APS: average particle size, \%TDS: percentage total dissolved solids, \%EY: extraction yield.
For roasted coffee (Fig 4.a and b), PC1, which explains $62.54 \%$ of the total variance, is mainly defined by the positive influence of the OTA content, \%TDS, porosity, moisture, CBD, \%EY and negatively by APS, which also presented a very strong and strong correlation with the OTA (Fig. 3.a), confirming an OTA relationship with properties related to the solute extraction capacity of the matrix. PC2 explains $20.582 \%$ of the variance and is mainly characterized by $\mathrm{pH}, \mathrm{FLD}$, color $\left(a^{*}, b^{*}\right.$, $\left.c^{\star}\right)$ and $a_{w^{\prime}}$ so they are probably not associated with OTA content. The PC3 that explains $12.22 \%$ of the variance is mainly characterized by physical properties such as color $\left(a^{*}, b^{*}, c^{*}\right)$, density (FLD and CBD), and ASP. For soluble coffee (Fig. 4.c and d), the PC1 that explains $42.12 \%$ total variance is mainly defined by the influence of the moisture content and $a_{w^{\prime}}$ OTA, color $\left(a^{*}, b^{*}\right.$ and $\left.c^{*}\right), \% T D S$, and porosity. The PC2 explains $17.94 \%$ of the total variance, which is defined by the FLD, ASP, porosity, and $a^{\star}$. The PC3 that explains 15.59 $\%$ of the total variance, is explained by the $\mathrm{pH}$, OTA, CBD, and \%TDS. The PCA formed three groups of samples, specifically GR, WB1, and WB2 (Fig. 4.a and b) for roasted coffee; and SD, A, and FD for soluble coffee (Fig. 4.c and d).

The CA was performed based on the principal component analysis (PCA). Fig. 5 shows the distribution of samples within the groups according to PC1 and PC2, which were harmonically grouped according to the type of coffee associated with its commercial presentation and industrial process, OTA content, and ASP. In the case of roasted coffee (Fig. 5.a) two groups were distinguished, in whole beans (Cluster 1) and ground (Cluster 2), which in turn corresponded to coffees with a high content of OTA, porosity, \%TDS, \%EY, and low ASP (Cluster 1); and coffees with low OTA content, porosity, \%TDS, $\% E Y$, and high ASP (Cluster 2). For soluble coffee (Fig. 5.b) three groups were observed, the group of coffees spray-dried in fine powder and agglomerated (Cluster 1 and 2), where cluster 1 grouped the two types of soluble coffee with more OTA content and less ASP; and the other group consisted of freezedried coffees (Cluster 3 ), which in turn had the lowest OTA content and the highest ASP, likewise, as seen in Fig. 5.c, the CA clearly confirmed the separation between roasted coffee (Cluster 1 ) and soluble coffee (Cluster 2), which similarly represented the coffees with lower (Cluster 1) and higher (Cluster 2) OTA content. This method of dimension reduction could provide beneficial information to determine the relationship between OTA content and physical and physicochemical properties associated with the extraction capacity of coffee solutes. 


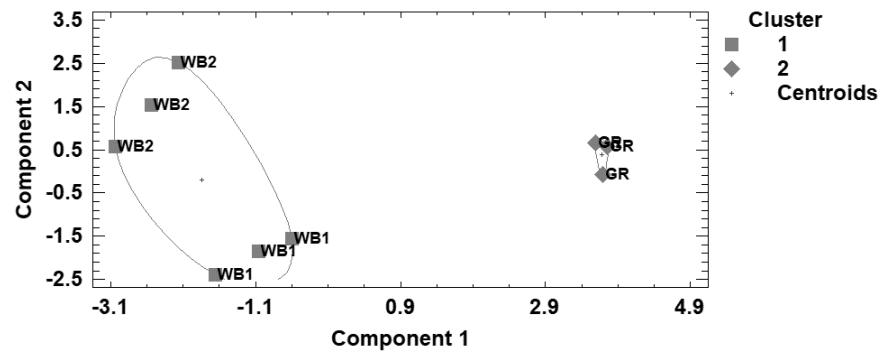

a)

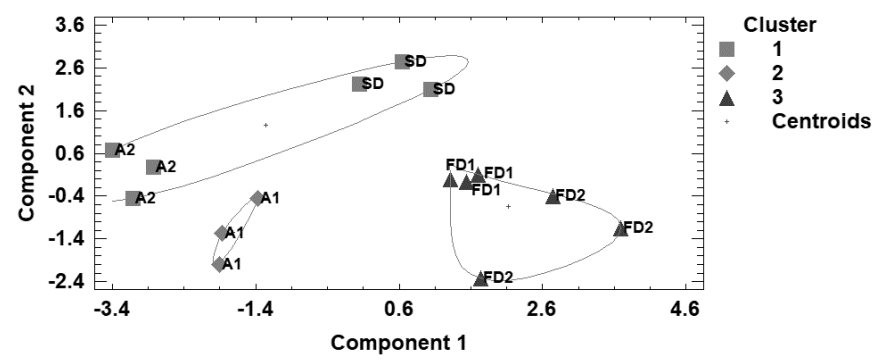

b)

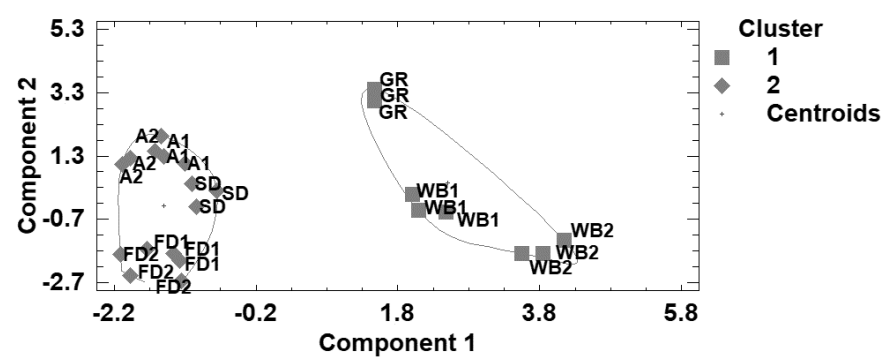

c)

Figure 5. Clusters formed from Colombian coffee samples according to PC1 and PC2. (a) roasted coffee, (b) soluble coffee, (c) roasted and soluble coffee. For sample codes refer to Table 1.

\section{DISCUSSION}

The highest presence $(p<0.05)$ of OTA in soluble coffee compared to roasted coffee could be because soluble coffee is subjected to a concentration process of the extract previously obtained from roasted coffee. Therefore, the OTA concentration could double its value (35), like other soluble components (13). Also, soluble coffee is usually made with "pasilla" (defective quality coffee), while roasted coffee with few quality defects that corresponded to excelsior coffee (WB2) and presented approximately 11 times less OTA content. The OTA content in Colombian coffee was also studied by Diaz et al. (2004) (36) accuracy, intermediate precision, linearity, limit of detection, limit of quantitation, and ruggedness. The method was found to be selective for OTA in both matrices tested. Recovery rates from soluble coffee samples ranged from 73.5 to $91.2 \%$, and from green coffee samples from 68.7 to $84.5 \%$. The intermediate precision (RSDr, who used immunoaffinity columns and HPLC, and found an average OTA content of 10 $\mu \mathrm{g} / \mathrm{Kg}$ for green coffee and a mean and maximum concentration of 6.8 and $19.4 \mu \mathrm{g} / \mathrm{Kg}$ for soluble coffee, respectively, a similar result to the obtained in the present study. In other research, Franco et al. (2014) (19) used the ELISA method to detect OTA in Panama green coffee, finding OTA contents in the range of $4.90-37.73 \mu \mathrm{g} / \mathrm{Kg}$, three of which exceeded the limits defined by European legislation (12). Regarding the toxicological aspect, and considering the assumptions proposed by Galarce-Bustos et al. (2014) (37), the per-capita coffee consumption in Colombia is 2.85 cups per day (38), therefore a daily intake (ID) of OTA is estimated from a coffee drink made from samples with the lowest (WB2) and highest (A2) OTA content, of 0.247 and 4.403 ng, which represent 1.46 and $25.89 \%$ of the total ID (IDT) established by the Scientific Committee on Food of the European Commission EFSA (17 ng/ $\mathrm{kg}$ body weight/day) (39), or 1.77 and $31.45 \%$ of the IDT established by the Joint FAO/WHO Expert Committee on Food Additives (14 ng/kg b.w/day) (40).

OTA content was grouped and positively correlated with \%EY, \%TDS, ASP, porosity, CBD, and moisture. Castaño et al. (2000) (41) found that at low ASP, higher \%EY, and soluble solids content from the coffee drink were obtained, because at low ASP there is a greater area for mass transfer, which could explain the relationship between OTA content and \%EY, \%TDS, and ASP. The above-mentioned indicates that their relationship is based on the ability to extract solutes from coffee. Similarly, these authors reported that the lowest \%EY and soluble solids content were obtained from low-quality coffee (pasillas), which in fact, are susceptible to yeast and mold contamination due to their post-harvest handling and consequently higher OTA contents, which is consistent with the results obtained in the present study. Likewise, it has been reported that at low APS, there is high porosity (42). Also high CBD is obtained when there are high porosity values (29), which determines the mass transfer during extraction (42), confirming the possible explanation of the relationship of porosity and CBD with the OTA content given its solubility at high extraction temperatures. Although the moisture was related to the OTA content, the variables $a_{w^{\prime}} p H$, and color ( $a^{*}$, $b^{*}$, and $c^{*}$ ) were not grouped with the OTA content. Therefore, this probably did not influence the OTA's presence, which indicates that there was probably no production of OTA in processed and packaged coffee, as confirmed by the results of the yeast and mold counts. 


\section{CONCLUSIONS}

Through the application of the ELISA immunoassay technique, the quantification of OTA in coffee samples from the Colombian market was achieved, obtaining a variable range of OTA, where soluble coffees presented a higher $(p<0.05)$ OTA contents than roasted coffees and $25 \%$ of the samples exceeded the limits established by the regulations, representing 1.77 and $31.45 \%$ of the IDT of OTA defined by JECFA. The OTA content presented a significant and positive grouping and correlation ( $p<0.05$ ) with \%EY, \%TDS, ASP, porosity, and $\mathrm{CBD}$, confirming the interdependence of these variables, which are associated with the extraction capacity of coffee solutes. In contrast, the other physical properties studied did not show important relationships with the OTA content. The yeast and mold count showed values within the regulations' limits, showing that the OTA present in the coffee samples comes from stages prior to the coffee production and packaging process.

\section{ACKNOWLEDGEMENTS}

The authors would like to thank to the Committee for the Development of Research-CODI-University of Antioquia, Colombia for their financial support (Project code: CIQF277), and to the research groups of Inmunología Celular e Inmunogenética (GICIG) and of Estabilidad de Medicamentos y Alimentos (GEMCA) for their support in this study.

\section{AUTHORS' CONTRIBUTIONS}

All authors participated equally in the development and writing of this research.

\section{CONFLICTS OF INTEREST}

The authors declare no conflict of interest in the present investigation.

\section{REFERENCES}

1. Folmer B, Farah A, Jones L, Fogliano V. Human WellbeingSociability, Performance, and Health. In: Former B, editor. The Craft and Science of Coffee. Academic Press; 2017. Chapter 20. DOI: https://doi.org/10.1016/B978-0-12-803520-7.00020-7

2. Malir F, Ostry V, Pfohl-Leszkowicz A, Malir J, Toman J. Ochratoxin A: 50 years of research. Toxins. 2016; 8(7): 191. DOI: https://doi. org/10.3390/toxins8070191
3. García-Moraleja A, Font G, Mañes J, Ferrer E. Development of a new method for the simultaneous determination of 21 mycotoxins in coffee beverages by liquid chromatography tandem mass spectrometry. Food Res Int. 2015; 72: 247-55. DOI: https://doi. org/10.1016/j.foodres.2015.02.030

4. Vieira T, Cunha S, Casal S. Mycotoxins in Coffee. In: Preedy, editor Coffee in Health and Disease Prevention. San Diego: Academic Press; 2015. Chapter 25. DOI: https://doi.org/10.1016/B978-0-12409517-5.00025-5

5. Gamboa-Gaitán MÁ. Presence of Aspergillus and other fungal symbionts in coffee beans from Colombia. Acta Biológica Colomb. 2012;17(1): 39-50.

6. Cabañes FJ, Bragulat MR. Black aspergilli and ochratoxin A-producing species in foods. Curr Opin food Sci. 2018; 23: 1-10. DOI: https://doi.org/10.1016/j.cofs.2018.01.006

7. Kulahi A, Kabak B. A preliminary assessment of dietary exposure of ochratoxin A in Central Anatolia Region, Turkey. Mycotoxin Res. 2020; 36: 327-337. DOI: https://doi.org/10.1007/s12550-02000397-6

8. Leitão AL. Occurrence of Ochratoxin A in Coffee: Threads and Solutions-A Mini-Review. Beverages. 2019; 5(2): 36. DOI: https:// doi.org/10.3390/beverages5020036

9. Federación Nacional de Cafeteros. Informe Gerente General. 86 Congreso General de Cafeteros. https://federaciondecafeteros. org/app/uploads/2019/12/Informe-del-Gerente-al-87-CongresoNacional-de-Cafeteros-2019.pdf. 2018. (accessed 26 May 2021)

10. Federación Nacional de Cafeteros. Informe Gerente General. 85 Congreso Nacional de Cafeteros. https:// educafeseducacioncafetera.files.wordpress.com/2017/12/ caficultor-informacion-congreso-cafetero-2017.pdf. 2017. (accessed 26 May 2021)

11. Ministerio de salud y Protección y protección Social. Resolución 4506 de 2013. Por la cual se establecen los niveles máximos de contaminantes en los alimentos destinados al consumo humano y se dictan otras disposiciones. Santafé de Bogotá, D.C.: Ministerio de salud y Protección y protección Social. 2013.

12. European Commission. Commission Regulation (EU) No 105/2010 of 5 February 2010 amending Regulation (EC) No 1881/2006 setting maximum levels for certain contaminants in foodstuffs as regards ochratoxin A. In: Official Journal of the European Union. 2010. p. 7-8.

13. Contreras-Calderón J, Mejía-Díaz D, Martínez-Castaño M, BedoyaRamírez D, López-Rojas N, Gómez-Narváez F, et al. Evaluation of antioxidant capacity in coffees marketed in Colombia: Relationship with the extent of non-enzymatic browning. Food Chem. 2016; 209: 162-70. DOI: https://doi.org/10.1016/j.foodchem.2016.04.038

14. Xiong $Y$, Leng $Y$, Li X, Huang $X$, Xiong $Y$. Emerging strategies to enhance the sensitivity of competitive ELISA for detection of chemical contaminants in food samples. TrAC Trends Anal Chem. 2020; 126: 115861. DOI: https://doi.org/10.1016/j.trac.2020.115861

15. Fadlalla MH, Ling S, Wang R, Li X, Yuan J, Xiao S, et al. Development of ELISA and lateral flow immunoassays for ochratoxins (OTA and OTB) detection dased on monoclonal antibody. Front Cell Infect Microbiol. 2020;10: 80. DOI: https://doi.org/10.3389/ fcimb.2020.00080

16. Vieira T, Cunha S, Casal S. Analysis of the Mycotoxin Ochratoxin A in Coffee. In: Preedy VR, editor. Coffee in Health and Disease Prevention. Academic Press; 2015. Chapter 112. DOI: https://doi. org/10.1016/B978-0-12-409517-5.00112-1

17. Dohnal V, Dvořák V, Malír F, Ostrý V, Roubal T. A comparison of ELISA and HPLC methods for determination of ochratoxin $A$ in 
human blood serum in the Czech Republic. Food Chem Toxicol. 2013; 62: 427-31. DOI: https://doi.org/10.1016/j.fct.2013.09.010

18. Zheng Z, Hanneken J, Houchins D, King RS, Lee P, Richard JL. Validation of an ELISA test kit for the detection of ochratoxin A in several food commodities by comparison with HPLC. Mycopathologia. 2005;159(2): 265-72. DOI: https://doi. org/10.1007/s11046-004-8663-3

19. Franco H, Vega A, Reyes S, De León J, Bonilla A. Niveles de Ocratoxina A y Aflatoxinas totales en cafés de exportación de Panamá por un método de ELISA. Arch Latinoam Nutr. 2014; 64(1): 42-9.

20. Guzmán EMQ, Guerrero FA, Chaves JA. Determinación de ocratoxina A en plasma humano y en café de Costa Rica por un método de ELISA. Arch Latinoam Nutr. 2007; 57(2): 168-72.

21. R-Biopharm $\mathrm{GmbH}$. Column Immunoaffinity column for sample clean up prior to analysis of ochratoxin A. RIDA ${ }^{\circledR}$ Ochratoxin A Art. No.: R1303. https://r-biopharm.com. (accessed 26 May 2021)

22. Biopharm $\mathrm{GmbH}$. Enzyme inmmunoassay for quantitative analysis of Ochratoxin A. A 30/15 Art NR1311. https://r-biopharm.com/. (accessed 26 May 2021)

23. Ruiz Márquez AF, Pazmiño-Arteaga JD, Pérez YL, Gallardo Cabrera C, Hernández Arcia YM. Estudio de estabilidad acelerado en café verde: una aproximación sensorial. Rev Lasallista Investig. 2019;16(1):93-102. DOI: https://doi.org/10.22507/rli.v16n1a13

24. Association of Official Analytical Chemists (AOAC). Official Methods of Analysis of the 18th International AOAC. Horwitz W, Latimer, G. W. J, editors. Gaithersburg: AOAC; 2005.

25. Yüksel AN, Özkara Barut KT, Bayram M. The effects of roasting, milling, brewing and storage processes on the physicochemical properties of Turkish coffee. LWT. 2020; 131: 109711. DOI: https:// doi.org/10.1016/j.Iwt.2020.109711

26. Stokes CN, O'Sullivan MG, Kerry JP. Hedonic and descriptive sensory evaluation of instant and fresh coffee products. Eur Food Res Technol. 2017; 243(2): 331-40. DOI: https://doi.org/10.1007/ s00217-016-2747-4

27. Instituto Colombiano de Normas Técnicas y Certificación. NTC4602-1. Determinación del rendimiento de la extracción y de los sólidos solubles en la bebida de café, parte I: método de goteo. Bogotá; 1999.

28. Instituto Colombiano de Normas Técnicas y Certificación. NTC 4912-1. Café soluble. Determinación de la densidad por caída libre y compactación. Bogotá; 2016.

29. Sahin S, Sumnu SG. Size, Shape, Volume, and Related Physical Attributes. In: Physical Properties of Foods Food Science Text Series. New York, NY: Springer; 2006. Chapter 1. DOI: https:// doi.org/10.1007/0-387-30808-3_1

30. Instituto Colombiano de Normas Técnicas y Certificación. Café tostado y molido. Método para la determinación del tamaño promedio de partícula por distribución granulométrica. NTC 2441. Bogotá; 2011.

31. Instituto Colombiano de Normas Técnicas y Certificación. Café instantáneo (soluble). NTC 4159. Bogotá; 2015.

32. Instituto Colombiano de Normas Técnicas y Certificación. Café tostado, en grano o molido. NTC 3435. Bogotá; 2012.

33. Sun Z, Duan Z, Liu X, Deng X, Tang Z. Development of a nanobodybased competitive dot ELISA for visual screening of Ochratoxin A in cereals. Food Anal Methods. 2017; 10(11): 3558-64. DOI: https://doi.org/10.1007/s12161-017-0915-1

34. Babu SC, Sanyal P. Indicators and causal factors of nutrition application of correlation analysis. In: Suresh C. Babu, Shailendra N. Gajanan and Prabuddha Sanyal, editors. Food Security, Poverty and Nutrition Policy Analysis. San Diego: Academic Press; 2014. Chapter 8. DOI: https://doi.org/10.1016/B978-0-12-4058644.00008-9

35. Blanc M, Pittet A, Muñoz-Box R, Viani R. Behavior of Ochratoxin A during Green Coffee Roasting and Soluble Coffee Manufacture. J Agric Food Chem. 1998; 46(2): 673-5. DOI: https://doi. org/10.1021/j99707703

36. Diaz GJ, Ariza D, Perilla NS. Method validation for the determination of ochratoxin $A$ in green and soluble coffee by immunoaffinity column cleanup and liquid chromatography. Mycotoxin Res. 2004; 20(2): 59-67. DOI: https://doi.org/10.1007/ BF02946736

37. Galarce-Bustos $O$, Alvarado M, Vega M, Aranda M. Occurrence of ochratoxin $A$ in roasted and instant coffees in Chilean market. Food Control. 2014; 46: 102-7. DOI: https://doi.org/10.1016/j. foodcont.2014.05.014

38. Quijano J, Lopez J. El consumo de café en Medellín desde la perspectiva del comportamiento del consumidor. EIA. 2010; 6(3): 145-57.

39. EFSA. Opinion of the scientific panel on contaminants in the food chain on a request from the commission related to ochratoxin $A$ in food. EFSA J. 2006; 365: 1-56. DOI: https://doi.org/10.2903/j. efsa. 2006.365

40. JECFA. Joint FAO/WHO Expert Committee on Food Additives (JECFA): Evaluation of certain mycotoxins in food. 2002. Rome: FAO.

41. Castaño J, Quintero G, León V. Caracterización de rendimiento de extracción y el contenido de sólidos solubles en la bebida de café. Cenicafe. 2000; 51(3): 185-95.

42. Cordoba N, Fernandez-Alduenda M, Moreno FL, Ruiz Y. Coffee extraction: A review of parameters and their influence on the physicochemical characteristics and flavour of coffee brews. Trends Food Sci Technol. 2020; 96: 45-60. DOI: https://doi. org/10.1016/j.tifs.2019.12.004 